Article

\title{
Avoiding the Inappropriate: The European Commission and Sanctions under the Stability and Growth Pact
}

\author{
Martin Sacher \\ Submitted: 3 December 2020 | Accepted: 11 February 2021 | Published: 27 May 2021
}

Institute of Political Science, University of Luxembourg, 4366 Esch-sur-Alzette, Luxembourg; E-Mail: martin.sacher@uni.lu

\begin{abstract}
Fiscal policy surveillance, including the possibility to impose financial sanctions, has been an important feature of Economic and Monetary Union since its inception. With the reform of fiscal rules in the aftermath of the financial and sovereign debt crisis, coercive provisions have been made stricter and the Commission has formally gained power vis-à-vis the Council. Nevertheless, sanctions under the Stability and Growth Pact for budgetary non-compliance have so far not been imposed. This article asks why the Commission has until now refrained from proposing such sanctions. Using minimalist process-tracing methods, three post-crisis cases in which the imposition of fines was possible, are analysed. Applying an adaptation of normative institutionalism, it is argued that the mechanism entitled "normative-strategic minimum enforcement" provides an explanation of why no sanctions are imposed in the cases studied: Given that the Commission does not perceive punitive action as appropriate, it strategically refrains from applying the enforcement provisions to their full extent.
\end{abstract}

\section{Keywords}

European Commission; fiscal policy coordination; fiscal surveillance; logic of appropriateness; process-tracing; sanctions; Stability and Growth Pact

Issue

This article is part of the issue "Reforming the Institutions of Eurozone Governance" edited by Anna-Lena Högenauer (University of Luxembourg), David Howarth (University of Luxembourg) and Moritz Rehm (University of Luxembourg).

(C) 2021 by the author; licensee Cogitatio (Lisbon, Portugal). This article is licensed under a Creative Commons Attribution 4.0 International License (CC BY).

\section{Introduction}

Rules on fiscal policy surveillance and financial sanctions have been an integral part of Economic and Monetary Union (EMU) since its inception. These provisions have, however, always been a source of dispute. After a softening of the EU's budgetary surveillance framework in 2005, additional reforms were deemed necessary in the aftermath of the financial crisis and the subsequent sovereign debt crisis. Amongst others, this latest reform intended to limit the role of the Council concerning the imposition of sanctions (EU Regulation of 16 November 2011, 2011). The reform has indeed formally increased the Commission's power vis-à-vis the Council (Bauer \& Becker, 2014; Dehousse, 2016; Seikel, 2016; Van Aken \& Artige, 2013), without, however, discarding from the rulebook the flexibility provisions introduced in 2005.
While the application of the surveillance rules was never a purely technical exercise, the degree to which political considerations should interfere with technical surveillance is the source of recurrent debate. Similarly, the respective roles of the Council and Commission, as well as their relationship, are far from consensual and static. While at the beginning of EMU, the Commission was supposed to act as the technical supervisory authority, it has become clear under President Juncker that the Commission is willing to enforce the budgetary rules politically. This development continued under Commission President von der Leyen, under whom the fiscal requirements of the Stability and Growth Pact (SGP) were even temporarily suspended in the wake of the COVID-19 crisis. Despite the post-crisis reinforcement of coercive provisions, the Commission has indeed applied the SGP flexibly (Mabbett \& Schelkle, 2014; Schmidt, 
2016), and has not proposed sanctions based on the SGP for non-compliance with fiscal recommendations, although this would have been possible in several cases. This article, therefore, asks how we can best explain why the Commission has so far refrained from proposing financial sanctions.

This article will draw upon an adaptation of normative institutionalism. It argues that while actor behaviour follows a logic of appropriateness, actors act strategically to pursue their objectives. Applying minimalist processtracing methods, Commission behaviour is explained by a mechanism that is entitled "normative-strategic minimum enforcement." It argues that because punitive action is not perceived as appropriate in the cases at hand, the Commission strategically refrains from applying existing enforcement provisions to their full extent.

This article will draw upon three post-crisis cases in which the imposition of sanctions for fiscal noncompliance was possible. These are the cases of Belgium in 2013, France in 2015 and the double-case of Spain and Portugal in 2016.

The article is organised as follows. In the next section, the development of EU fiscal surveillance rules is presented. Following this, the theoretical assumptions of normative institutionalism and their implications for the case studies are explained. After turning to the article's methodology, the cases are analysed as explained above. The article ends with a summary of the findings and concluding remarks.

\section{Rules and Rule Change in EU Fiscal Policy Surveillance}

Fiscal policy surveillance has been a fundamental part of EMU since its introduction with the Maastricht Treaty in 1992. It aims to prevent and correct budgetary deficits and debt levels that respectively exceed 3\% and $60 \%$ of a country's GDP. With the Excessive Deficit Procedure (EDP), the possibility to impose financial sanctions for non-compliance with the fiscal requirements was present from the beginning of EMU. The degree to which coercive provisions should be automatic, the level of political discretion and the Council's control over the EU's executive, were, however, constant sources of political disagreement (see Heipertz \& Verdun, 2010). The SGP, adopted in 1997, consists of a preventive and a corrective arm, with the latter operationalising the application of the EDP (Heipertz \& Verdun, 2010; see also Council Regulation of 7 July 1997, 1997). The SGP was first reformed in 2005. This reform consisted in making the SGP more flexible in that it, for example, relaxed the definition of what counts as 'exceptional economic circumstances' in the assessment of the member states' fiscal situation (Heipertz \& Verdun, 2010, p. 168). Also, it introduced the possibility to adopt a revised Art. 126(7) recommendation with a new deadline for the correction of an excessive deficit if a country has taken effective action, but 'unexpected adverse economic events with major unfavourable consequences for government finances' had occurred (Council Regulation of 27 June 2005, 2005, p. 7).

In reaction to the sovereign debt crisis, fiscal rules were again reformed. The Six-Pack-the first set of measures reforming the SGP in the wake of the crisis-entered into force in December 2011. Sanctions for non-compliance with fiscal obligations could now be introduced earlier and are more automatic. If for example, the Council, upon a Commission recommendation, and per Art. 126(8) of the Treaty on the Functioning of the European Union (TFEU, 2016), finds that a member state has not taken effective action to correct its excessive deficit, the Commission is now required to recommend to the Council the imposition of a fine of up to $0.2 \%$ of the member state's GDP (EU Regulation of 16 November 2011, 2011, Art. 6(1)). The Commission can, however, recommend to the Council to reduce or cancel the fine, on grounds of 'exceptional economic circumstances or following a reasoned request by the Member State concerned' (EU Regulation of 16 November 2011, 2011, Art. 6(4)). In addition, with the introduction of Reverse Qualified Majority Voting (RQMV), Commission recommendations under the corrective arm of the SGP are considered as adopted by the Council, unless there is a qualified majority that rejects them (Bauer \& Becker, 2014; EU Regulation of 16 November 2011; Treaty on Stability, Coordination and Governance in the Economic and Monetary Union, 2012, Art. 7).

For the Commission and its role in fiscal surveillance and enforcement, this means that it has seen its competences and powers enhanced (Bauer \& Becker, 2014; Dehousse, 2016). RQMV and the possibility to trigger sanctions earlier in the procedure are likely to add 'significant political weight to the recommendations of the Commission' (Bauer \& Becker, 2014, p. 220). The Commission, at least on paper, has certainly gained power vis-à-vis the Council, as it is now more difficult for the member state representatives to reverse the Commission's recommendations. This simultaneously gives the Commission a large degree of discretion concerning the interpretation of fiscal rules (Dehousse, 2016; Seikel, 2016; Van Aken \& Artige, 2013).

Indeed, despite the reinforcement of coercive provisions in the framework of the SGP, policy-makers have not taken back the above-mentioned flexibility provisions that were introduced with the 2005 reform. What is more, the Six-Pack has introduced even more exemption provisions that form the so-called "general escape clause" (see European Commission, 2020). Therefore, considerable flexibility still exists concerning the assessment of the fiscal performance of member states (see also Mabbett \& Schelkle, 2014). In its application of the reformed economic governance framework, the Commission has indeed shown flexibility (Bekker, 2016) and leniency (Mabbett \& Schelkle, 2014). Using its discretion, the Commission has even reshaped the 
coordination process (Vanheuverzwijn, 2017) and has re-interpreted the governing rules, applying them more and more flexibly (Schmidt, 2016, 2020). While the Commission under President Barroso did not acknowledge its flexible application of the rules and hid behind an austerity-oriented discourse, the Juncker Commission made its more political and flexible stance public (Schmidt, 2016, 2020). Nevertheless, the Commission appears to signal its role as a determined supranational surveillance body by increasing the number of countryspecific recommendations to member states with a more polarised public opinion regarding the EU (van der Veer \& Haverland, 2018). While aiming at presenting itself as empathetic towards member state authorities, the Commission seems to avoid showing too much leniency, suggesting that it tries to find the right balance in its application of economic and fiscal surveillance rules (see Vanheuverzwijn, 2017). Still, since the sovereign debt crisis and through policy-learning, the views of Commission officials have moved away from austerity orientation towards a flexible and politicised view on fiscal governance (Miró, 2020). In a similar vein, the Commission, in its approach towards the Art. 7 procedure concerning the non-respect of the rule of law, prefers to find a solution in cooperation with the government in breach of the rules, rather than resorting to force (Closa, 2019).

\section{Theory}

In this article, it will be argued that although actors strategically pursue their objectives, these objectives are shaped by the actors' perception of appropriate action. An adaptation of normative institutionalism can help us theorise and operationalise this claim. Normative institutionalism is rooted in sociology and emphasises the role of institutional norms that proclaim appropriate action. In that, it can be distinguished from sociological institutionalism, which focuses more on cognitive aspects, such as the perception and interpretation of situations and problems, and less on the actors' political behaviour (Peters, 2019).

Normative institutionalism assumes that action is driven by rules, which prescribe appropriate behaviour (March \& Olsen, 2011). Rules contain 'codes of meaning,' which 'facilitate interpretation of ambiguous worlds,' and 'embody collective and individual roles, identities, rights, obligations, interests, values, world-views, and memory' (March \& Olsen, 2011, p. 484). Consequently, actors act according to what they perceive is appropriate given their role and position (see March \& Olsen, 1989). Rules, however, are sometimes ambiguous. A change in the situation in which actors find themselves may therefore lead them to match the rules to the new situation. This realignment consists of a 'constructive interpretation' of the rules. By 'fitting a rule to a situation,' appropriateness is established (March \& Olsen, 2011, p. 483).

Although normative institutionalism does not exclude cost-benefit calculations (see March \& Olsen,
2011), the central role that the logic of appropriateness plays in the approach lends a structuralist tendency to it, which leaves little room for agency (see Peters, 2019). Therefore, and building upon the sociological critique of the distinction between the logic of appropriateness and the logic of consequentialism, it is assumed here that the two logics stand in an interdependent relationship: while actors act strategically in pursuing their objectives, these objectives are shaped by their institutional and social environment (see Jenson \& Mérand, 2010).

Based on these theoretical assumptions and the findings of the literature review presented above, the following expectations regarding Commission behaviour can be derived. Given the Commission's discretion and the ambiguity of the SGP, the fiscal surveillance rules need to be interpreted by Commission actors in light of the situation at hand and in line with their perception of their role and obligations. Thereby, appropriate action is established. The main ambiguity of the rules stems from their openness in that both a strict and flexible reading and application are possible, and that the rules, therefore, allow for ideologically, economically and politically opposing policy choices to take form. The rules might further enter into conflict with wider policy objectives the Commission is pursuing, which reinforces the necessity to align rule application and perceived obligations. The literature suggests that the Commission perceives a flexible application of the rules-taking into account the political, social and economic impact of its actionsas appropriate (see Miró, 2020; Schmidt, 2020), without however neglecting that being too lenient does not correspond to its role as surveillance body (see van der Veer \& Haverland, 2018; Vanheuverzwijn, 2017). In any case, finding solutions cooperatively is expected to be preferred to resorting to punitive action (see Closa, 2019), especially because sanctions might be seen as inappropriate given that under the SGP they would impose further costs on a country that is already in an economically difficult situation (see Hodson \& Maher, 2004). In pursuing the objectives, it deems appropriate, the Commission is expected to act strategically.

\section{Methodology}

\subsection{Process-Tracing}

The above-mentioned expectations regarding Commission behaviour will be tested in three case studies, applying minimalist theory-testing process-tracing methods. Process-tracing allows us to trace a causal mechanism that links a trigger or event $X$ and an outcome $Y$ (Fontaine, 2020; see also Beach \& Pedersen, 2019; Bennett \& Checkel, 2015). Serving as a first test of the existence of a causal link, in minimalist process-tracing, the causal mechanism is not unpacked in its entirety (Beach \& Pedersen, 2019). Nevertheless, mechanisms can still consist of different parts that are conceptualised as 'entities that engage in activities' (Beach \& Pedersen, 2019, p. 3) 
and linked 'in a relationship of conditional dependence' (Beach \& Pedersen, 2019, p. 36). After spelling out what fingerprints we expect the activities to have left, we have to examine whether our empirical observations confirm these expectations. If this is the case, the observations can be regarded as mechanistic evidence that supports our claims concerning the existence and functioning of our theorised mechanism (see Beach \& Pedersen, 2019; Smeets \& Beach, 2020). The Supplementary File 1 provides an overview of the case-specific observations.

Process-tracing allows for making within-case causal inferences. However, we can also analyse several typical cases-that is cases in which the cause and the outcome are present-and examine whether the theorised causal mechanism functions in the same way across our population of cases. At least at the level of abstraction of the theorised mechanism, this then shows that the cases are mechanistically homogenous (Beach \& Pedersen, 2019).

A mechanism provides only one possible link between a trigger and an outcome, as $X$ and $Y$ can be linked by several different mechanisms. Only if one claims that a mechanism excludes other mechanisms, it is, therefore, necessary to 'formulate alternative explanations' (Beach \& Pedersen, 2019, p. 43; see also Beach \& Smeets, 2020).

In this article, it will be argued that the mechanism entitled "normative-strategic minimum enforcement" links trigger-an EDP at a stage where the introduction of sanctions is possible-and outcome-the non-imposition of financial sanctions. It argues that because punitive action is not perceived as appropriate, the Commission strategically refrains from applying the enforcement provisions to their full extent. Building upon expectations derived from the literature review and the theoretical approach of this article, the mechanism consists of two parts.

Part 1 of the mechanism consists of the European Commission assessing member states' fiscal performance within the boundaries of the flexibility of the rules. The Commission respects the limits of the flexibility of the SGP concerning the assessment of fiscal performance, fulfilling its role as surveillance body and Guardian of the Treaties. At the same time, the use of flexibility provisions seems warranted if the data on fiscal performance indicates a borderline case, as, in such a situation, punitive action is not perceived as appropriate.
The fingerprints that would confirm the functioning of this part are official documents, news coverage or interview data that show that the Commission saw the numbers as clear and accordingly respected the limits of the flexibility it possesses, or that it saw the numbers as unclear, which justified the use of relevant flexibility provisions.

Part 2 of the mechanism consists of the European Commission trying to avoid punitive action, resorting to a flexible reading of the rules. Financial sanctions are seen as inappropriate by the dominant Commission actors because they are not in line with their perception of the Commission's role in fiscal policy surveillance. Therefore, the Commission applies the rules in a way that does not lead to the imposition of sanctions and accordingly acts strategically in pursuing its objectives.

The fingerprints that would confirm the functioning of this part are documents, news coverage or interview data that indicate that the Commission believed that the imposition of sanctions would not have been appropriate and that it read and applied the rules flexibly.

\subsection{Case Selection}

Although financial sanctions based on the SGP for noncompliance with fiscal recommendations have never been imposed, there have been instances in which taking such a procedural step was possible. For this study, three cases have been selected that occurred after the first post-crisis reform of sanction provisions with the Six-Pack. These cases only concern euro area members, as SGP provisions regarding financial sanctions only apply to this group of member states.

The cases selected are presented in Table 1. All cases have in common that the member states concerned were under an EDP and did not receive a financial sanction. The cases diverge, however, in the procedural steps undertaken. The case of France serves as a highly politicised example of cases in which establishing noneffective action and thereby triggering sanctioning provisions was theoretically possible but not carried out. The cases of Belgium, Spain and Portugal are the only euro area post-crisis cases in which non-effective action was established. Despite this finding, the Commission did not issue a recommendation concerning sanctions in the case of Belgium. While the Commission issued a formal

Table 1. Overview of case studies.

\begin{tabular}{|c|c|c|c|c|}
\hline Case & $\begin{array}{l}\text { Existence of } \\
\text { excessive deficit } \\
\text { (Art. 126(6) of } \\
\text { the TFEU) }\end{array}$ & $\begin{array}{l}\text { Establishment of } \\
\text { non-effective } \\
\text { action (Art. 126(8) } \\
\text { of the TFEU) }\end{array}$ & $\begin{array}{l}\text { Formal } \\
\text { recommendation } \\
\text { concerning sanctions } \\
\text { (EU Regulation } \\
\text { No. } 1173 / 2011 \text {, Art. 6) }\end{array}$ & $\begin{array}{l}\text { Recommendation/ } \\
\text { imposition of } \\
\text { sanctions }\end{array}$ \\
\hline France 2015 & Yes & No & - & - \\
\hline Belgium 2013 & Yes & Yes & No & - \\
\hline Spain and Portugal 2016 & Yes & Yes & Yes & No \\
\hline
\end{tabular}


recommendation in the case of Spain and Portugal, it proposed to cancel the fines. As the steps under the respective EDPs of Spain and Portugal were largely dealt with jointly by the Commission, the two cases are treated here mostly as a single analytical entity.

For this article, 22 semi-structured expert interviews have been conducted with European Commission officials both at service (DG ECFIN) and Cabinet-level and with National Government officials in Finance Ministries and at Permanent Representations to the EU. The data gathered will be used to uncover and confirm actions, positions and perceptions of key actors. For triangulation, this article will additionally draw on official documents and news coverage. Each interview was attributed a code (see Supplementary File).

\section{Analysis}

Three post-crisis cases will be analysed, in which the imposition of sanctions for fiscal non-compliance was a valid option for decision-makers-Belgium in 2013, France in 2015 and Spain and Portugal in 2016. In line with process-tracing methods, each case study aims at exploring whether the mechanism entitled "normativestrategic minimum enforcement" was present and functioned as theorised.

\subsection{Belgium 2013}

As the first euro area country under the reformed rules, and still under the Barroso II Commission, Belgium was found not to have taken effective action to correct its excessive deficit. In light of this decision, the Belgian government was facing the potential imposition of a fine under the rules of the Six-Pack. However, the Commission did not issue any recommendation concerning sanctions.

The trigger was that in 2009, in the wake of the financial crisis, an EDP was opened for Belgium. At that point, a deadline was set for the Belgian government to correct its excessive deficit by 2012.

Part 1 of the "normative-strategic minimum enforcement" mechanism suggests that the Commission assesses fiscal performance within the boundaries of flexibility: In 2013, the Commission assessed whether Belgium had taken effective action concerning the Art. 126(7) Council recommendation it had received in 2009. It found that it had failed to do so. It seems that the data clearly indicated that Belgium had not achieved its fiscal objectives.

Evidence shows that the decision to establish noneffective action was seen as rather technical. The Commission's assessment clearly showed that Belgium had not undertaken the required action (COM 1). According to the Commission's assessment, even without the recapitalisation of the Dexia banking group that amounted to $0.8 \%$ of its GDP, Belgium would have missed its deficit correction deadline (European Commission, 2013b). Even the Belgian administration perceived the decision as a rather technical step that was in line with the country's fiscal performance (MS 2).

Part 2 of this mechanism suggests that the Commission tries to avoid punitive action: After the Council confirms the Commission's assessment of non-effective action, the latter is required to issue a recommendation to the Council concerning the imposition of sanctions. This recommendation can either contain a fine, or the cancellation thereof. However, despite the Council confirming that Belgium had not taken effective action, the Commission did not issue any formal recommendation. The Commission apparently resorted to a flexible reading of the rules to avoid punitive action in this case.

Evidence shows that in the decision not to propose sanctions, legal considerations and arguments have played a major role. The Belgian EDP had been launched in 2009 and a Council recommendation was issued. It is in response to this recommendation that in 2013 the Commission deemed that Belgium had not taken effective action. The Six-Pack, based on which the establishment of non-effective action should lead to a proposal concerning sanctions, however, only entered into force in December 2011. The Commission's legal service questioned the legal firmness of proposing a sanction in this case (COM 1, COM 2). Indeed, a transition periodalthough not necessarily mandatory-for the application of fines is foreseen in the recitals of the relevant Regulation (EU Regulation of 16 November 2011, 2011, Recital 21). In this vein, Olli Rehn, Vice-President and Commissioner for Economic and Monetary Affairs at the time explained:

As the six-pack legislation of reinforced economic governance entered into force only in mid-December 2011, imposing a fine for the years 2010 or 2011 could go against the principle of non-retroactivity which is essential in European law. In my view, therefore, it would be neither fair nor legally sound to apply it retroactively to those years. (European Commission, 2013a)

According to a Commission official, the possibility of Belgium not paying the fine, of discussing the decision being warranted, or of a court proceeding could have undermined the credibility of the rules (COM 2). Pursuing the normative goal of good cooperation and the legality and credibility of the rules in force, the Commission-in its strategic thinking-therefore took into account that the imposition of sanctions might have undermined achieving its objectives.

Evidence suggests that how the European Commission handled the French EDP in 2013 had also played a role in the decision. Given that the Commission aims at a consistent approach towards all member states, Commission officials deemed it possible that the lenient approach with regard to France, which at the time was about to receive a two-year deadline extension (Fontanella-Khan, 2013), might have contributed to 
the Commission not proposing a sanction for Belgium (COM 3, COM 6).

Although Belgium did not fully deliver upon the Council's fiscal recommendations, it did not enter into an open conflict with the surveillance framework, and therefore the Commission did not see a reason to punish Belgium (COM 1). In a similar vein, Olli Rehn stated in a college meeting that the 'undertakings on fiscal consolidation given by the present Belgian government' and the 'absence of a fully operational government' in 2010 and 2011 were reasons not to impose a financial sanction (European Commission, 2013c, pp. 21-22).

In summary, when assessing the fiscal performance of the Belgian government, the Commission found that the numbers clearly indicated non-compliance with the recommendations. Therefore, it applied the rules in line with its role as Guardian of the Treaties. However, when it came to proposing sanctions against the Belgian government, the Commission opted for a prudent approach, not applying the newly introduced provision, as it was in conflict with several other norms. The legality of rule application, its consistency, and the cooperative behaviour of the Belgian government were valued by Commission actors and were in line with their perception of what the Commission should aim for. They accordingly concluded that sanctions that would undermine these norms were not appropriate. In interpreting the rules and setting aside a new provision to achieve the objectives it deemed appropriate, the Commission acted strategically.

\subsection{France 2015}

In 2015, asked by reporters why the Commission did not sanction France for non-compliance with the fiscal rules, Jean-Claude Juncker, then President of the Commission, simply answered 'because it is France' (Guarascio, 2016). Although this answer could potentially be explained by Mr Juncker's distinctive sense of humour, it seemed to confirm widely-held suspicions about the application of the SGP. But was France treated differently simply because of its size and weight within the EU? Or are there other factors that explain the non-imposition of sanctions in this case?

The trigger was that an EDP was opened for France in 2009. In 2013, the deadline to correct the excessive deficit was extended for two years-until 2015.

Part 1 of the mechanism was set in motion, and in early 2015 the Commission assessed the French government's compliance with the Art. 126(7) Council recommendation it had received in 2013. In its analysis of France's progress under the EDP, the Commission services did not come up with a clear assessment. While the so-called 'bottom-up assessment' indicated that France had complied with the Council recommendation, the 'top-down assessment' showed a 'shortfall of $0.2 \%$ of GDP compared to the recommendation' (European Commission, 2015b, p. 13). In line with this unclear picture, the Commission's overall assessment of the French budgetary efforts stated that '... the information available does not allow to conclude that the recommended effort has not been delivered in 2013-2014' (European Commission, 2015b, p. 13). It seems that given the unclear data, the Commission has assessed the French fiscal performance using the flexibility of the rules.

The French case was the first major decision of the Juncker Commission in the area of the SGP. Evidence shows that in line with its announcement to be a "political" Commission, it had already made clear in January 2015 that it would use the flexibility that the SGP provides (see European Commission, 2015a). As acknowledged by a Commission official interviewee, the assessment of the French fiscal situation was borderline, also because the indicators the Commission is working with at this stage are complex and sometimes difficult to observe (COM 2). In line with the political and flexible approach in the area of the SGP under the Juncker Commission, 'the bar of evidence required to step up a procedure is relatively high,' with the French case being an example of this (COM 2). According to another Commission official, given this unclear picture, the Commission gave France the benefit of the doubt (COM 1). It did so by effectively-notwithstanding the double-negative phrasing-concluding that France had taken effective action, despite the weak numerical basis for this.

Part 2 of the mechanism proposes that the Commission tries to avoid punitive action: In its assessment, the Commission did not detect non-effective action, which if found and adopted by the Council would have required a proposal regarding sanctions. Instead, it recommended extending the deadline for the deficit correction for two years. It seems that the Commission has resorted to a flexible reading of the rules to prevent punitive action.

Evidence shows that a pattern emerged during this case regarding the internal conflict lines and balance of power in the area. This pattern consisted of Pierre Moscovici, Commissioner for Economic and Monetary Affairs, being the advocate of a more flexible approach and Vice-President Valdis Dombrovskis, responsible for the Euro and Social Dialogue, advocating a more rigid application of the rules. President Juncker emerged as taking on the role of arbiter (COM 3; see also Schmidt, 2020). Commissioner Moscovici argued that the Commission must be politically and technically credible and must therefore use expertise and the legal rules as the basis for making the right political decisions.' He was further of the opinion 'that the European Semester was an opportunity for the Commission to send messages to the member states to correct their... budget deficits' and that 'the Commission's general approach must strike the right balance between encouragement and a demand for results' (European Commission, 2015d, pp. 26-27). In light of the Commission's aim of encouraging reforms, Commissioner Moscovici saw the imposition of sanctions as a failure for both the Commission and the 
member state concerned (see Chassany \& Barker, 2015). Vice-President Dombrovskis, however, believed that 'any relaxing of these rules... would risk undermining the procedure itself and the equity of this procedure, as well as the Commission's power to apply it' (European Commission, 2015d, p. 26).

Other than Vice-President Dombrovskis, 'a halfdozen other Commissioners,' including Vice-President Katainen and Commissioner Vestager, were in favour of concluding that no effective action had been taken (Spiegel, 2015). In the absence of a compromise between Commissioner Moscovici and Vice-President Dombrovskis, President Juncker backed Moscovici, and concessions were made to Dombrovskis regarding the extension of the deadline, granting two-more years instead of three (Spiegel, 2015), although there were voices in the Council that were already critical of a twoyear extension of the deadline (MS 1, MS 2).

Effectively concluding that France had taken effective action, together with the finding that the economic situation was weaker than expected when the recommendation had been issued, allowed the Commission-according to Art. 3(5) of Regulation (EC) No 1467/97-to extend the correction deadline (see European Commission, 2015c). Accordingly, sanctioning a member state based on rather weak and inconclusive figures and taking the risk of receiving complaints afterwards was not in line with the Commission's approach on fiscal policy surveillance (COM 2) and its perception of appropriate action.

In summary, the fiscal data were borderline and subject to interpretation by the Commission, using the flexibility that the SGP provides. Against the background of unclear data, a flexible reading of the rules was applied to prevent punitive action that was deemed inappropriate in the situation at hand. Rather than resorting to punishment, the self-image of the dominant Commission actors proclaimed acting towards improving the fiscal and economic situation in the member state concerned.

\subsection{Spain and Portugal 2016}

Spain and Portugal came the closest to the imposition of sanctions. Both countries were found not to have taken effective action to correct their excessive deficits. While the Commission-as required by the rules of the Six-Pack-issued a formal recommendation to the Council concerning the imposition of financial sanctions, it recommended cancelling the fines.

The trigger was that Spain and Portugal had both been under the corrective arm of the SGP since 2009. In 2013, the deadline for the deficit correction for Spain was set for 2016 and the one for Portugal for 2015.

Part 1 of the mechanism was set in motion and, in 2016, the Commission assessed the action of both member states concerning their respective Council recommendations. It found that both countries had not taken effective action to correct their excessive deficits. The fis- cal data, therefore, seem to have clearly indicated the countries' non-compliance with the recommendations.

Evidence shows that Commission actors saw the establishment of non-effective action for both Spain and Portugal as a rather technical and straightforward decision as the numbers were clear (COM 1, COM 2, COM 4, COM 5, COM 7). So unlike in the case of France, in this case, the establishment of non-effective action directly resulted from the analysis of the fiscal performance.

Part 2 of the mechanism suggests that the Commission tries to avoid punitive action: The Commission issued formal recommendations concerning sanctions following the Council's confirmation of non-effective action. However, the recommendations contained the cancellation of the fines. The Commission, therefore, seems to have resorted to a flexible application of the rules to prevent punitive action.

Evidence shows that, confronted with the legal requirement to envisage punitive action against Spain and Portugal, there was a division within the Commission. On the one hand, Commission actors in line with the tougher approach represented by Vice-President Dombrovskis thought that the imposition of sanctions, although of a symbolic amount (COM 5), would have served the credibility of the fiscal surveillance framework (COM 4, COM 5; see also Coman, 2018; Schmidt, 2020). On the other hand, a strict application of the rules was opposed by those Commission actors that were more in line with the approach followed by Commissioner Moscovici (see Coman, 2018; Schmidt, 2020). In particular, the thought was that financial fines would have been an additional fiscal burden, which could potentially have had counterproductive effects (COM 2).

In a similar vein, punitive action was not perceived as appropriate given the effort both countries had made in the previous years (COM 2, COM 3). In light of this situation, a fine would have been difficult to justify for the Commission, as stated by a Commission official:

The political and the public perception of the Commission proposing a fine... on countries that were emerging from that sort of economic backdrop and with that social backdrop still present... would simply have been impossible for people to understand. And so Commissioner Moscovici was very much of the view that sanctions were neither desirable nor appropriate in that particular case. (COM 3)

A closely related aspect was of particular importance in the Commission's assessment of the appropriateness of punitive action-the member states' willingness to cooperate. Both countries were seen as being cooperative and were not questioning the surveillance framework or intentionally disregarding their fiscal obligations (COM 1, COM 2, COM 4, COM 7). As one Commission official put it: 'Spain and Portugal... did not deserve...to be punished because their fiscal performance, all in all, despite not being in line, was not in open conflict with the EU frame- 
work' (COM 1). With regard to other EU institutions, such as the Council, given 'a broad European consensus in favour of cancelling the fines,' Commissioner Moscovici further 'felt it wise not to take the risk of provoking unnecessary divisions' (European Commission, 2016, p. 28). Ultimately, the Commission took a political decision in not proposing sanctions (COM 1). It did so by taking into account the reasoned requests submitted by the two governments, which allows the Commission to recommend to the Council the reduction or cancellation of a fine (EU Regulation of 16 November 2011, 2011, Art. 6(4)).

In summary, the assessment of the two member states' fiscal performance clearly showed that they had missed their objectives. Accordingly, the limits of the flexibility provisions were respected and no leniency was shown. However, when it came to the requirement to propose sanctions, the Commission took into account the economic, social and political situation, including the countries' recent effort and their willingness to cooperate, and potential opposition from other institutions including the Council. Given the dominant actors' self-image as representing a political body that aims at supporting economic improvement, sustaining a cooperative oversight system and being responsive to the respective situation, they concluded that sanctions were not appropriate in the situation at hand. Consequently, the Commission applied the rules flexibly to prevent the imposition of sanctions.

\section{Conclusion}

Despite the reinforcement of coercive provisions with the post-crisis reform of fiscal policy surveillance and the strengthened role of the European Commission, it has so far refrained from proposing financial sanctions for non-compliance with fiscal recommendations. This article aims to understand the Commission's behaviour in this regard. Applying an adaptation of normative institutionalism, it is argued that the Commission strategically refrains from using coercive provisions to their full extent because sanctions are not perceived as appropriate in the cases at hand. Testing this assumption, a minimalist process-tracing analysis shows that the mechanism of "normative-strategic minimum enforcement" was present and functioned as theorised in the three post-crisis cases of near-imposition of fines.

When assessing member states' fiscal performance, the Commission acts within the boundaries of its flexibility. If the data clearly indicates non-compliance, the Commission states that no effective action has been taken. In line with its role as Guardian of the Treaties, it avoids showing too much leniency. If, however, the data on fiscal performance is less clear, it uses the flexibility of the SGP and avoids steps that might lead to punitive action. Even if based on its assessment of non-effective action, the Commission is immediately required to envisage sanctions, it applies the rules in a way that ultimately does not lead to the imposition of fines. Financial sanctions are seen as an inappropriate measure by the dom- inant Commission actors for several reasons. They are economically counterproductive, they might create conflict with member states that could damage the credibility of the overall surveillance framework and they would be difficult to justify vis-à-vis the European public. They accordingly go against the actors' self-image of the Commission as an institution that should work towards a cooperative and growth-enhancing system of economic and fiscal policy coordination and surveillance. In a context of ambiguous rules, a strict reading of the rules is therefore set aside to the benefit of a flexible reading. This means that the Commission acts strategically in pursuing the objectives it deems appropriate. On a theoretical level, this shows that strategy and normguided action can co-exist. While the theorised and confirmed norm-based mechanism provides one explanation of Commission behaviour, it is well conceivable that other theories and mechanisms equally explain why the Commission refrains from triggering sanctions. More research needs to be done to understand the explanatory value of other factors.

Regarding the mechanism's external validity, it is conceivable that a similar mechanism provides an explanation of the outcome in the case of Italy in 2018-2019. As in the cases studied in this article, the imposition of sanctions for Italy was discussed but finally avoided by the European Commission (see Schmidt, 2020). However, in the course of discussions, the Italian government moved its position from the overt rejection of the EU's fiscal surveillance framework to a more cooperative stance. Given the conflictual behaviour of the Italian government, extending the explanatory value of the causal mechanism might make a slight adaptation necessary to sufficiently take into account the specificities of the case. This could be the task of subsequent research.

To conclude, despite the reinforcement of coercive provisions under the SGP, there is no automaticity in their application. Cooperative behaviour and reform effortseven if small-are sufficient for the Commission in order not to resort to punitive action. The idea of a cooperative relationship between the Commission and member states shapes the practice and the politics of the SGP and appears to trump considerations concerning the potential benefits that may result from imposing financial sanctions. Despite some hawkish voices within the Commission, most Commission actors seem less and less inclined to trigger financial sanctions under the SGP, thereby-at least indirectly-contesting the benefit and legitimacy of resorting to punitive measures. The European Fiscal Board, the Commission's independent advisory body on the implementation of fiscal rules, goes so far as to call for abandoning financial sanctions given their difficult enforceability in the current political context. Instead, it calls for a move towards a more incentivising framework (see European Fiscal Board, 2020). Surveillance under the SGP has been largely put on hold in the wake of the COVID-19 crisis and it is not yet clear when or if the EU will go back to applying the 
fiscal surveillance framework in its current form (see Fleming \& Brunsden, 2020). If the rules are not reformed and the current sanctioning provisions are maintained, they will most likely stay there, never to be applied (see European Fiscal Board, 2020), unless, perhaps, in the case of a member state's fundamental, overt and continuous rejection of the EU's fiscal surveillance framework.

\section{Acknowledgments}

I would like to thank Reinout van der Veer for his valuable input. I am also grateful for very helpful comments and suggestions made by Dermot Hodson, Matthias Kranke and by participants of the ECPR Joint Sessions 2020, the ECPR General Conference 2019 and the workshop organised in the context of this issue of Politics and Governance. Finally, my thanks to the editors Anna-Lena Högenauer, David Howarth and Moritz Rehm, and three anonymous reviewers for their constructive comments. Research for this article has been supported by the Luxembourg National Research Fund (FNR).

\section{Conflict of Interests}

The author declares no conflict of interests.

\section{Supplementary Material}

Supplementary material for this article is available online in the format provided by the author (unedited).

\section{References}

Bauer, M. W., \& Becker, S. (2014). The unexpected winner of the crisis: The European Commission's strengthened role in economic governance. Journal of European Integration, 36(3), 213-229.

Beach, D., \& Pedersen, R. B. (2019). Process-tracing methods: Foundations and guidelines ( $2 \mathrm{nd}$ ed.). Ann Arbor, MI: University of Michigan Press.

Beach, D., \& Smeets, S. (2020). The unseen hands: Collaborative instrumental leadership in the British renegotiation case. European Journal of Political Research, 59(2), 444-464.

Bekker, S. (2016). Is there flexibility in the European semester process? Exploring interactions between the EU and member states within post-crisis socioeconomic governance (Tilburg Law School Research Paper No. 10/2016). Stockholm: SIEPS. Retrieved from https://papers.ssrn.com/sol3/papers.cfm? abstract_id=2743238

Bennett, A., \& Checkel, J. T. (2015). Process tracing: From philosophical roots to best practices. In A. Bennett \& J. T. Checkel (Eds.), Process tracing: From metaphor to analytic tool (pp. 3-38). Cambridge: Cambridge University Press.

Chassany, A.-S., \& Barker, A. (2015, February 25). France and Italy granted reprieve for breaching budget limits. Financial Times. Retrieved from https:// www.ft.com/content/a41a2998-bd13-11e4-990200144feab7de

Closa, C. (2019). The politics of guarding the Treaties: Commission scrutiny of rule of law compliance. Journal of European Public Policy, 26(5), 696-716.

Coman, R. (2018). How have EU 'fire-fighters' sought to douse the flames of the eurozone's fast- and slowburning crises? The 2013 structural funds reform. The British Journal of Politics and International Relations, 20(3), 540-554.

Council Regulation (EC) No 1467/97 of 7 July 1997 on speeding up and clarifying the implementation of the excessive deficit procedure. (1997). Official Journal of the European Union, L 209/6.

Council Regulation (EC) No 1056/2005 of 27 June 2005 amending Regulation (EC) No $1467 / 97$ on speeding up and clarifying the implementation of the excessive deficit procedure. (2005). Official Journal of the European Union, L 174/5.

Dehousse, R. (2016). Why has EU macroeconomic governance become more supranational? Journal of European Integration, 38(5), 617-631.

European Commission. (2013a). Press speaking points at the European semester press conference. European Commission. Retrieved from https://ec.europa.eu/ commission/presscorner/detail/en/speech_13_481

European Commission. (2013b). Recommendation for $a$ Council decision establishing that no effective action has been taken by Belgium in response to the Council Recommendation of 2 December 2009 (COM(2013) 381 Final). Brussels: European Commission.

European Commission. (2013c). Minutes of the 2048th meeting of the Commission (PV(2013) 2048 Final). Brussels: European Commission.

European Commission. (2015a). Making the best use of the flexibility within the existing rules of the Stability and Growth Pact (COM(2015)12 Final). Brussels: European Commission.

European Commission. (2015b). Commission staff working document analysis by the Commission services of the budgetary situation in France following the adoption of the Council recommendation to France on 21 June 2013 with a view to bringing an end to the situation of an excessive government deficit (SWD(2015) 19 Final). Brussels: European Commission.

European Commission. (2015c). Recommendation for a Council recommendation with a view to bringing an end to the excessive government deficit in France (COM(2015) 115 Final). Brussels: European Commission.

European Commission. (2015d). Minutes of the 2117th meeting of the Commission (PV(2015) 2117 Final). Brussels: European Commission.

European Commission. (2016). Minutes of the 2179th meeting of the Commission (PV(2016) 2179 Final). Brussels: European Commission.

European Commission. (2020). Communication from the 
Commission to the Council on the activation of the general escape clause of the Stability and Growth Pact (COM(2020) 123 Final). Brussels: European Commission.

European Fiscal Board. (2020). Annual report 2020. Brussels: European Fiscal Board. Retrieved from https://ec.europa.eu/info/sites/info/files/efb_ annual_report_2020_en_1.pdf

European Union. (2011). Regulation (EU) No 1173/2011 of the European Parliament and of the Council of 16 November 2011 on the effective enforcement of budgetary surveillance in the euro area. Official Journal of the European Union, L 306/1.

Fleming, S., \& Brunsden, J. (2020, August 9). National budget rules to remain suspended next year, Brussels says. Financial Times. Retrieved from https:// www.ft.com/content/d7c41c76-e301-4257-8684f7fe50ec0563

Fontaine, G. (2020). Process tracing for comparative policy analysis: A realist approach. In B. G. Peters \& G. Fontaine (Eds.), Handbook of research methods and applications in comparative policy analysis (pp. 277-295). Cheltenham and Northampton, MA: Edward Elgar Publishing.

Fontanella-Khan, J. (2013, May 28). EU's 'sacrificial lamb' faces fines for breaching deficit limits. Financial Times. Retrieved from https://www.ft.com/content/ 0d7e13f4-c79d-11e2-be27-00144feab7de

Guarascio, F. (2016, May 31). EU gives budget leeway to France 'because it is France'-Juncker. Reuters. Retrieved from https://uk.reuters.com/article/ukeu-deficit-france-idUKKCNOYM1NO

Heipertz, M., \& Verdun, A. (2010). Ruling Europe: The politics of the Stability and Growth Pact. Cambridge: Cambridge University Press.

Hodson, D., \& Maher, I. (2004). Soft law and sanctions: Economic policy co-ordination and reform of the Stability and Growth Pact. Journal of European Public Policy, 11(5), 798-813.

Jenson, J., \& Mérand, F. (2010). Sociology, institutionalism and the European Union. Comparative European Politics, 8(1), 74-92.

Mabbett, D., \& Schelkle, W. (2014). Searching under the lamp-post: The evolution of fiscal surveillance (LEQS Paper No. 75/2014). London: LSE. http://dx.doi.org/ 10.2139/ssrn.2434008

March, J. G., \& Olsen, J. P. (1989). Rediscovering institutions. The organizational basis of politics. New York, NY: The Free Press.

March, J. G., \& Olsen, J. P. (2011). The logic of appropri- ateness. In R. E. Goodin (Ed.), The Oxford handbook of political science (pp. 478-497). Oxford: Oxford University Press.

Miró, J. (2020). Austerity's failures and policy learning: Mapping European Commission officials' beliefs on fiscal governance in the post-crisis EU. Review of International Political Economy. Advance online publication. https://doi.org/10.1080/09692290.2020. 1749868

Peters, B. G. (2019). Institutional theory in political science: The new institutionalism (4th ed.). Cheltenham and Northampton, MA: Edward Elgar Publishing.

Schmidt, V. A. (2016). Reinterpreting the rules 'by stealth' in times of crisis: A discursive institutionalist analysis of the European Central Bank and the European Commission. West European Politics, 39(5), 1032-1052.

Schmidt, V. A. (2020). Europe's crisis of legitimacy: Governing by rules and ruling by numbers in the eurozone. Oxford: Oxford University Press.

Seikel, D. (2016). Flexible austerity and supranational autonomy. The reformed excessive deficit procedure and the asymmetry between liberalization and social regulation in the EU. JCMS: Journal of Common Market Studies, 54(6), 1398-1416.

Smeets, S., \& Beach, D. (2020). Political and instrumental leadership in major EU reforms. The role and influence of the EU institutions in setting-up the Fiscal Compact. Journal of European Public Policy, 27(1), 63-81.

Spiegel, P. (2015, March 8). Olli Rehn slams EU successors for failing to punish France. Financial Times. Retrieved from https://www.ft.com/content/ 02eb3086-c596-11e4-ab8f-00144feab7de

Treaty on Stability, Coordination and Governance in the Economic and Monetary Union, 2012.

Treaty on the Functioning of the European Union, 2016.

Van Aken, W., \& Artige, L. (2013). Reverse majority voting in comparative perspective: Implications for fiscal governance in the EU. In B. de Witte, A. Héritier, \& A. H. Trechsel (Eds.), The euro crisis and the state of European democracy (pp. 129-161). Florence: European University Institute.

van der Veer, R. A., \& Haverland, M. (2018). Bread and butter or bread and circuses? Politicisation and the European Commission in the European Semester. European Union Politics, 19(3), 524-545.

Vanheuverzwijn, P. (2017). How the Commission fills in the blanks of the European Semester: Incomplete contracts and supranational discretion in the EU's post-crisis economic governance. Politique Européenne, 55(1), 8.

\section{About the Author}

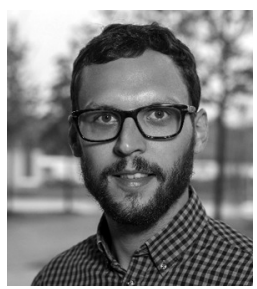

Martin Sacher is a Doctoral Researcher in political science at the University of Luxembourg. His work focuses on the role of the European Commission in the enforcement of the Stability and Growth Pact, with an emphasis on the application of sanctioning provisions. He holds Master's Degrees in political science from the University of Münster, Sciences Po Lille and the College of Europe (Bruges). 